\title{
EFL secondary teachers' assessment literacy: Assessment conceptions and practices
}

\author{
Roghibatul Luthfiyyah *1, Iin Wariin Basyari ${ }^{2}$, Dwiniasih ${ }^{3}$ \\ ${ }^{1,3}$ English Education Department, Faculty of Teacher Training and Education, Universitas \\ Swadaya Gunung Jati Cirebon, Jawa Barat, Indonesia \\ 2 Elementary School Teacher Department, Faculty of Teacher Training and Education, \\ Universitas Swadaya Gunung Jati Cirebon, Jawa Barat, Indonesia \\ * roghibatul@unswagati.ac.id (Corresponding Author)
}

\begin{abstract}
Assessment literacy is defined as knowledge, conceptions, and skills to conduct an assessment. Having sufficient assessment literacy levels, teachers can assist students in improving learning and in achieving learning outcomes. This study employs a descriptive quantitative design that explores EFL secondary teachers' assessment literacy and assessment practice. The data were gathered using an online survey and semi-structured interviews. Forty-eight respondents willingly fulfilled an online questionnaire containing 32 questions adapted from the Teachers Assessment Literacy Questionnaire (TALQ). The data obtained from the survey were analyzed using descriptive statistics. Furthermore, three participants representing each assessment literacy level were selected for interviews to explore their classroom assessment practice. The interview data were analyzed using thematic analysis in terms of the conceptions of assessment, the procedure of assessment construction, and some challenges in assessment practice. The findings reveal that EFL secondary teachers generally have a moderate assessment literacy level. However, the participants reflect different conceptions of assessment, procedures, and challenges in assessment practice depending on an individual level of assessment literacy, institutional and national policies, and socio-culture factors. It shows that assessment literacy is not a single element that can influence teachers' assessment practices.
\end{abstract}

Keywords: assessment literacy; conceptions of assessment; assessment practice; EFL secondary teachers 
How to cite this paper (in APA style): Luthfiyyah, R., Basyari, I. W., \& Dwiniasih. (2020). EFL secondary teachers' assessment literacy: Assessment conceptions and practices. Journal on English as a Foreign Language, 10(2), 402421. https://doi.org/10.23971 ßefl.v10i2.2101

DOI: https://doi.org/10.23971/jefl.v10i2.2101

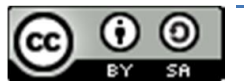

Copyright (C) 2020 THE AUTHOR(S). This article is distributed under a Creative Commons Attribution-ShareAlike 4.0 International license.

An assessment has been widely acknowledged as a prominent activity in the teaching and learning cycle (Bijsterbosch et al., 2019; Cheng \& Fox, 2017). It is not surprising that assessment plays a vital role in the classroom. Scholars reported that teachers spend up to a quarter to half of their professional time performing classroom assessments to monitor students' achievement towards learning outcomes and assist students and teachers in promoting learning (DeLuca \& Klinger, 2010; Lam, 2015). As the primary agent in classroom assessment practices, teachers must have adequate knowledge and skills to assess the students accurately. The result of the assessment consequently will have a meaningful impact on the learning and teaching instruction quality (Pastore \& Andrade, 2019). To this end, the teacher obligates to be assessment literate.

The term of assessment literacy was firstly coined by Stiggins (1991) over two decades for general education. He depicts teachers who have adequate assessment literacy know what and how to assess, what the potential matters will be, and how to handle those problems. Furthermore, there are specifically seven elements that teachers need in assessment literacy. They select the assessment methods that fit learning objectives, developing assessment methods appropriate for learning goals. They also use assessment outcomes to make decisions about student ability levels, improve teaching quality, evaluate curriculum, improve school quality, collect and make scores and interpret existing data. Besides, they develop a valid assessment procedure, communicating assessment outcomes to students, parents, ordinary people, and understanding other ethical, illegal, and inappropriate assessment methods. In a narrow context, the term language assessment is defined as the teachers' knowledge, skills, and language assessment (Fulcher, 2012; Levi \& InbarLourie, 2020; Scarino, 2013). In short, assessment literacy covers many aspects, from knowledge to practice, that can improve both learning quality and teaching instruction.

Journal on English as a Foreign Language, 10(2), 421

p-ISSN 2088-1657; e-ISSN 2502-6615 
Although assessment literacy is perceived as a central issue in language teaching, some scholars assert that assessment literacy is a complex issue interconnecting various aspects, such as experiment, socio-cultural, policy, personal beliefs, and others (Livingston \& Hutchinson, 2017). Pastore and Andrade (2019) represent a model of assessment literacy development, consisting of the following elements: teachers' knowledge base, assessment conceptions, school and national socio-cultural policy, assessment literacy practice, teachers' learning, and teachers' identity as the assessor. Meanwhile, Lam (2019) attempts to simplify those factors into three significant elements. They are knowledge base, assessment conceptions, and assessment literacy practice. Those three components will be elaborated further in this study.

There have been an increasing number of studies scrutinizing teachers' assessment knowledge. The results from many empirical studies regrettably report that most of the teachers generally have an inadequate level of assessment knowledge and skills. They have less capability to prepare learners for facing high-stake and low-stake assessments (Alkharusi et al., 2012; Duckor \& Perlstein, 2014; Koh, 2011; Lam, 2015; Yamtim \& Wongwanich, 2014). They also have less self-esteem about knowledge and skills of assessment, and they have due to their fewer inputs of understanding of classroom assessment development and implementation (Berry et al., 2019; Lam, 2019). Although teachers graduated from teacher education programs or courses, they only had minimum experience learning about educational assessment concepts and practices (Fan et al., 2011; Lam, 2015; Pastore \& Andrade, 2019). Moreover, teachers who are less equipped with assessment literacy must face the diversity of students' needs in the classroom and local and national educational assessment policy, which is frequently changing in a short period.

Regarding the discrepancies of the knowledge base, scholars still have the inconclusive voices that some professional training activities can contribute a significant effect in developing teacher assessment literacy (Fan et al., 2011; Koh, 2011; Koh et al., 2017; Lam, 2015). In their study, Fan et al. (2011) utilize information, communication, and technology (ICT) to facilitate the teachers' training model called P2R-WATA. The result shows that this model can improve teachers' assessment literacy and perspectives. Similar to the successful result from the previous study, Koh (2011) claims that the teachers who have attended the ongoing and sustainable teachers' training show significant improvement in assessment literacy in the second year of training compared to the teachers who attended one-shot professional training activity. On the other hand, the more recent study from Koh et al. (2017) reports that although 
teachers obtained new knowledge in designing tasks in authentic assessment, they found difficulties consolidating specific knowledge and skills in assessment criteria into their authentic assessment practices. Besides, Lam (2015) affirms his findings that language assessment training in Hong Kong involving five in-service English teachers failed to amalgamate assessment knowledge and implementation discrepancies. Furthermore, it is undoubtedly resumed that professional training is not merely an effort to facilitate the development of teachers' assessment knowledge.

As the assessment literacy keeps on evolving, the way teacher views assessment should be taken into consideration. Teacher conception of assessment refers to teachers' views, beliefs, perceptions about the nature of assessment - what they think about assessment, how it is structured, and what it is for. It is believed that the teachers' assessment conceptions have influenced their assessment practices (Barnes et al., 2017; Deneen \& Brown, 2016; Lam, 2019). Xu and Brown (2016) categorize two dimensions of the teacher's assessment: cognitive and affective. Cognitive represents a perception of teachers towards assessment purposes (assessment OF/FOR/AS learning). It is revealed as a typical result of previous studies. The teachers are more familiar with the psychometric assessment paradigm, which aims to measure and measure students' achievement towards objective learning rather than the interpretative paradigm of assessment, which focuses on the progressive improvement of learning and teaching instructions (Lee \& Coniam, 2013). As mentioned earlier, teachers should have had amalgamation views on both the paradigms (Deneen \& Brown, 2016).

On the other hand, the affective dimension points to teachers' emotions towards assessment (Lam, 2019). Some teachers have a definite system belief of assessment (e.g., assessment can improve students' learning), and others do not (e.g., assessment is bad, or the result of the assessment is invalid). Teacher's experiences in assessing, preparing, designing, and grading assessment practices in the classroom can impact the way they view the assessment in recent times (Looney et al., 2018; Vogt \& Tsagari, 2014). Consequently, teachers who have positive conceptions about assessment may find some merits from assessment practices, while the negative conceptions may resist or upset in practicing assessment (Vogt \& Tsagari, 2014). Thus, the teachers' conception of assessment is principal in assessment practices. Although it is argued that the change of conceptions usually requires a longer time than the change of assessment knowledge or skills (Deneen \& Brown, 2016), a sustainable professional development training which is conducted in an adequate time 
plays important roles in affecting emotional, perceptional, and cognitive domains of teachers towards assessment (Levy-Vered \& Alhija, 2018; Livingston \& Hutchinson, 2017).

The other component of assessment literacy is assessment practice. It is believed that the way teachers assess their students is interconnected with their assessment knowledge and conceptions. Previous empirical studies confirm the alignment between teachers' beliefs and assessment practices (Lee, 2013; Zulaiha et al., 2020). A study carried out by Lee (2013) reports that after receiving one-year training on writing assessment (obtaining knowledgebased), teachers change their conceptions of assessment, reflecting on their assessment practice. Besides, a recent quantitative study conducted by Zulaiha et al. (2020) confirms that teachers attempted to implement their assessment knowledge into practice. However, they face some discrepancies between their assessment knowledge and classroom assessment practice. The factors that commonly hinder institutional and national policies, students' attitudes, and parents' involvement in their children's education (Zulaiha et al., 2020). Thus, there is an urgency to scrutinize the alignment of assessment literacy, conceptions, and practice in a specific context.

Although many scholars have conducted studies on assessment literacy, similar studies in the Indonesian context are still underexplored. An empirical study was conducted in Indonesia by Prasetya (2018). He investigates the preservice teacher's assessment literacy by interviewing a student-teacher conducting teaching practice in school. The finding shows that the participant got more administrative test tasks than guidance on designing the assessment task. Furthermore, studies were carried out by Puspawati (2019) and Zulaiha et al. (2020). Puspawati (2019) reports her study that language assessment literacy of teachers in higher education in Indonesia, while Zulaiha et al. (2020) investigate the alignment of secondary teacher assessment literacy and practice quantitatively. A survey study on EFL secondary teachers' assessment literacy and practices seems sparse to be discussed from those empirical studies. To fulfill the gap, this study intends to explore EFL secondary teachers' assessment literacy and practices in terms of the conceptions of assessment, the procedures of assessment constructions, and some challenges in assessment practices from three participants representing each assessment literacy levels.

Accordingly, this study attempts to answer two research questions, "What is the level of EFL secondary teachers' assessment literacy?" and "How do EFL secondary teachers put their assessment literacy into practice (in terms 
of the conceptions of assessment, the procedures of assessment constructions, and some challenges in assessment practices)?"

\section{METHOD}

\section{Research Design}

This study employs a descriptive quantitative design. It aims to describe, classify, compare, contrast, analyze, and interpret an individual or a group's beliefs, point of view, attitude, or practice about a certain inquiry issue (Cohen et al., 2007, p. 205). In this study, a descriptive quantitative design utilizes to depict and categorize teachers' assessment literacy level on a large scale. An online survey was conducted to identify EFL secondary teachers' assessment literacy levels as the primary data. A semi-structured interview was held as the confirmation and the elaboration of how EFL secondary teachers put their assessment literacy into practice.

\section{Participants}

Forty-eight EFL secondary teachers voluntarily participated in an online survey. They are teachers from junior high schools $(n=20)$ and senior high school ( $n=28)$. Table 1 briefly depicts the participants' gender, age, background of education, and teaching experiences. The questionnaire's data were grouped into three levels; teachers who have a low level of assessment literacy, teachers who have a moderate level of assessment literacy, and teachers with a low level of assessment literacy. Three teachers, as a representative of each level, were voluntarily involved in the interview session. The interview sessions were conducted in pleasant places based on the participants' preferences.

Table 1. Demography data of participants

\begin{tabular}{llc}
\hline \multicolumn{1}{c}{ Demography } & \multicolumn{1}{c}{ Category } & $(\mathrm{n})$ \\
\hline Gender & Female & 30 \\
& Male & 18 \\
Age & 23-30 years old & 36 \\
& 31-40 years old & 10 \\
& 41-50 years old & 2 \\
Educational & Bachelor & 40 \\
background & Master & 8 \\
Teaching & < years & 22 \\
experience & 3-10 years & 16 \\
& 11-20 years & 10 \\
\hline
\end{tabular}

Journal on English as a Foreign Language, 10(2), 421

p-ISSN 2088-1657; e-ISSN 2502-6615 


\section{Data Collection}

The questionnaire was adapted from the Teachers Assessment Literacy Questionnaire (TALQ) from Plake et al. (1993). It comprises three sections to examine participants' demography information, personal experience in attending assessment training, and teachers' assessment literacy, consisting of 35 multiple choice items typed in Google Form. The questionnaire investigates EFL secondary teachers' assessment literacy level, which covers seven competencies of literacy assessments proposed by Stiggins (1991). The online questionnaire was then distributed through WhatsApp Teacher Support Group, known as Musyawarah Guru Mata Pelajaran (MGMP). The question items were tested to a group of teachers to check the items' validity and reliability before it is distributed.

After the questionnaire data were tabulated and analyzed, three groups of assessment literacy levels were classified. Three representative teachers from each level were invited to be involved in the interview. A semi-structured interview protocol consisting of three open-ended questions was prepared to address the second research question. The interview questions comprise the conceptions of assessment (including the importance and purposes of assessment), how teachers construct the assessment task, and the teachers' challenges and constraints during classroom assessment practice. Each interview session spent around 40 to 60 minutes using the Indonesian language. All the data were recorded using an audio recorder, transcribed carefully, and translated into the English language. During the interview, the interviewer attempted to maintain the interview flow as naturally as possible.

\section{Data Analysis}

The data obtained from the questionnaire were tabulated and analyzed statistically using SPSS. After screening and selecting the data, descriptive statistics, including mean and standard deviation, were calculated to summarize teachers' assessment literacy levels. The participants were categorized into three groups; low, moderate, and high levels. Three teachers, as the representatives from each level, were involved in the interview. The data from the interview were analyzed using thematic analysis (Braun \& Clarke, 2006). The recorded data from the interview were firstly transcribed verbatim and were repeatedly read to gain familiarization. Some words and phrases were then coded by labeling topics described and themed to address the research question. A thematic analysis was conducted to scrutinize the data for each case and across the cases.

Journal on English as a Foreign Language, 10(2), 421

p-ISSN 2088-1657; e-ISSN 2502-6615 


\section{FINDINGS}

The findings of this study are organized under research questions. It consists of two subsections that intend to display the data, elaborate on the findings, and provide some related previous studies. The first subsection is to report the EFL secondary teachers' assessment. The following subsection is to elaborate on the assessment literacy implementation in the classroom in terms of the conceptions of assessment, the procedures of assessment constructions, and some challenges in assessment practices.

\section{EFL Secondary Teachers' Assessment Literacy Level}

A set of the questionnaire covering seven assessment literacy indicators was distributed to identify EFL secondary teachers' assessment literacy level. The questionnaire data obtained from 48 teachers were analyzed using descriptive statistics. Table 2 illustrates a summary of the descriptive analysis result. It can be seen that the range of assessment literacy score is from 23.00 to 97.00, and the average score of teachers' assessment literacy $(\mathrm{N}=48)$ almost reaches the middle score $(\mathrm{M}=46.31)$. It means that the average of EFL secondary teachers' assessment literacy is moderate to low.

Table 2. A summary of descriptive statistics

\begin{tabular}{lccccc}
\hline & $\mathrm{N}$ & Minimum & Maximum & Mean & $\begin{array}{c}\text { Std. } \\
\text { Deviation }\end{array}$ \\
\hline $\begin{array}{l}\text { Teachers' assessment } \\
\text { literacy }\end{array}$ & 48 & 23.00 & 97.00 & 46.31 & 14.06 \\
Valid N & 48 & & 18 & & \\
\hline
\end{tabular}

Furthermore, Table 3 displays descriptive statistics of assessment literacy competences. The data reveals that EFL secondary teachers $(\mathrm{N}=48)$ have a better knowledge of selecting the assessment methods fit to learning objectives $(\mathrm{M}=64.16)$ and developing valid assessment procedures. In contrast, the participants neglect some ethical, illegal, and inappropriate assessment methods issues $(\mathrm{N}=21.66)$ and less considerate in utilizing the assessment results to improve students' learning quality, enhance teachers' instruction, or measure students' achievement. The vivid reasoning from teachers about their competences is rigorously investigated in the interview session. 
Table 3. A result of descriptive statistics for assessment literacy competences

\begin{tabular}{|c|c|c|c|c|c|c|}
\hline No & Competences & $\mathrm{N}$ & Minimum & Maximum & Mean & $\begin{array}{c}\text { Std. } \\
\text { Deviation }\end{array}$ \\
\hline 1 & $\begin{array}{l}\text { Selecting the assessment } \\
\text { methods that fit learning } \\
\text { objectives }\end{array}$ & 48 & 20 & 100 & 64.16 & 22.58 \\
\hline 2 & $\begin{array}{l}\text { Developing assessment } \\
\text { methods that are } \\
\text { appropriate with learning } \\
\text { goals }\end{array}$ & 48 & 0 & 100 & 56.66 & 31.77 \\
\hline 3 & $\begin{array}{l}\text { Making use of assessment } \\
\text { outcomes to make decisions } \\
\text { about student ability levels, } \\
\text { improving teaching quality, } \\
\text { evaluating curriculum, and } \\
\text { improving school quality }\end{array}$ & 48 & 0 & 100 & 27.08 & 26.89 \\
\hline 4 & $\begin{array}{l}\text { Collecting, making scores, } \\
\text { and providing an } \\
\text { interpretation of existing } \\
\text { data }\end{array}$ & 48 & 0 & 100 & 48.75 & 32.72 \\
\hline 5 & $\begin{array}{l}\text { Developing valid } \\
\text { assessment procedures }\end{array}$ & 48 & 0 & 100 & 62.50 & 32.12 \\
\hline 6 & $\begin{array}{l}\text { Communicating assessment } \\
\text { outcomes to students and } \\
\text { parents }\end{array}$ & 48 & 0 & 100 & 43.33 & 28.97 \\
\hline 7 & $\begin{array}{l}\text { Noticing other ethical, } \\
\text { illegal, and inappropriate } \\
\text { assessment methods }\end{array}$ & 48 & 0 & 100 & 21.66 & 27.31 \\
\hline
\end{tabular}

The participants are classified into three-level categories due to the practicality to invite participants involved in semi-structured interview categories (Table 4). A representative from each category will be voluntarily called for an interview.

Table 4. The categorizations of teachers' assessment literacy level

\begin{tabular}{clccc}
\hline Scale values & \multicolumn{1}{c}{ Categories } & $N$ & $f$ & $\%$ \\
\hline $0-35$ & Low level & 48 & 8 & 16.60 \\
$36-65$ & Moderate level & 48 & 37 & 77.00 \\
$66-100$ & High level & 48 & 3 & 6.22 \\
\hline
\end{tabular}




\section{The Implementation of Assessment Literacy}

Three teachers with different assessment literacy (AL) levels were willingly involved in a semi-structured interview to address the second research question. Table 5 illustrates the profile of participants who acknowledged their experiences in assessment practice. The interview sheds light on three main theme categories; teachers' conceptions of assessment, assessment task design procedures, and some challenges and constraints the teachers have during assessment practices.

Table 5. Profile of participants involved in interview

\begin{tabular}{|c|c|c|c|c|c|}
\hline Teacher & $\begin{array}{c}\text { Categories } \\
\text { of } \mathrm{AL}\end{array}$ & Gender & $\begin{array}{l}\text { Teaching } \\
\text { experience }\end{array}$ & $\begin{array}{l}\text { Educational } \\
\text { background }\end{array}$ & $\begin{array}{l}\text { Assessment of } \\
\text { training } \\
\text { experience }\end{array}$ \\
\hline T1 & Low level & Female & $11-15$ years & Master & Regional training \\
\hline $\mathrm{T} 2$ & Moderate level & Male & $0-5$ years & Bachelor & Never \\
\hline T3 & High level & Female & $\begin{array}{l}11-15 \\
\text { Years }\end{array}$ & Master & $\begin{array}{l}\text { Institutional, } \\
\text { national, and } \\
\text { international } \\
\text { training }\end{array}$ \\
\hline
\end{tabular}

\section{Teachers' Conceptions of Assessment}

The first interview question addressed to the participants is about the assessment conceptions, including the importance of assessment and its purposes. All participants express strong feelings that assessment is an integral part of the teaching and learning process because it can motivate students. However, T1 and T2 have a narrow purpose of assessment, which focuses on measuring students learning outcomes rather than enhancing students learning quality and redesigning better teaching instructions. T3 acknowledges that assessment has multiple purposes, such as: measuring students' competences, informing the students' weaknesses and strengths, and assisting the teachers' instruction of teaching. However, she admits that many of her colleagues have an assessment as a measurement paradigm.

T1: Yes, assessment is critical to check whether the students achieve the learning goals or not....

T2: ... As far I know, assessment is conducted by the teacher to measure the level of students' achievement in the form of a formative and summative test... 
T3: I personally believe that assessment is aiming at not only to measure students' ability, but it can also help me, as a teacher, to reflect my teaching and help the students to know where they are now and what they should do to improve their learning. Perhaps, this is just my ideal assessment aim, but I don't think that many teachers practice it.

Furthermore, from an affective dimension point of view, all participants agree that assessment positively impacts the students' motivation in learning. Nevertheless, T3 is concerned about the importance of positive and negative washback in the assessment.

T3: Assessment is like a coin that has two sides. It sometimes encourages learners or discourages them. Thus, teachers should consider the side effect of assessment...

All the participants generally agree that assessment can motivate the students to learn. However, the participants who have moderate and low assessment literacy levels tend to acknowledge assessment as an activity with a single objective to measure students' achievement. On the other hand, a participant who has a high assessment literacy level reckons that assessment does not merely measure the students' achievement. Still, it also assists teachers to monitor the students' learning improvement and to reflect teaching instructions.

\section{The Procedures of Assessment Construction}

Regarding the assessment task design procedures, the questions given are related to how the teachers construct the assessment task and what considerations they have during task design. When the question was addressed, all the participants spontaneously referred to the assessment task as a test. It confirms their conceptions of assessment to measure students' achievement rather than monitor the students' learning improvement. They usually construct a teacher-made test individually and then discuss the items with their colleagues before distributing the test to the students (T1, T2, T3).

T1: My friend and I (the teachers who teach English at the same level) respectively create a test using a guideline or blueprint from MGMP. Then, I discuss with my English teachers /colleagues in my school before we decide to give the test to the students.

Journal on English as a Foreign Language, 10(2), 421

p-ISSN 2088-1657; e-ISSN 2502-6615 
T2: ... because I am a novice teacher in this school. I adhere to my senior on how to design a test. We got a blueprint from school (not sure from school or MGMP), and we attempted to create a test based on the available guideline.

T3: ... I got those terms (validity, reliability, practicality, etc.) when I was in university. Moreover, I forgot the meaning of those terms. I usually check the materials' learning objectives, and then I create test items that are fit to learning goals. I am lucky to have a mentor teacher who taught me many things since I came to this school. I learned a lot from her how to conduct a good test.

Although the participants design the test based on the indicators or learning objectives from the syllabus and the blueprints of tests given by institution or $M G M P$, they tend to ignore some assessment principles, such as validity, reliability, practicality, etc. They confessed that they know those terms as the assessment of principles, but they don't understand how to implement them in assessment practice. In addition, the participants also need to see the indicators or learning objectives from the syllabus and the blueprints of tests given by MGMP.

\section{Some Challenges in Assessment Practice}

The participants admit that they found some issues that can hinder them in implementing classroom assessment. The issues are related to the limited facilities, lack of source of assessment knowledge, and the change of national assessment policy.

T1: ... The summative test in my school utilizes an online test application. The problem is that the application merely facilitates an objective test (e.g., multiple-choice question). So I can't give an essay test (and other subjective tests) to my students.... However, that's' not a big deal for me.

T2: ... to be honest, I am not really confident in conducting assessments. I need some inputs to develop my assessment literacy. The last time I learn about language assessment was when I was at university several years ago. I hope that the regional community of teacher professional development can conduct assessment training more often. Moreover, the national 
policy of conducting assessment changes often, and it makes me and my colleagues get lost sometimes.

T3: .... I think the teacher's main challenge in assessment practice is how to keep up with the national assessment policy. As you know, the curriculum changes often, and of course, it affects the assessment policy....

Further conversation from T2 and T3 emphasizes that teachers need some training that specifically discusses a national curriculum's standard assessment. They believe that some assessment training can help teachers' burnout in classroom assessment practice.

\section{DISCUSSION}

This study attempts to investigate EFL secondary teachers' assessment literacy and practice. Based on the result of an online survey using the Teachers Assessment Literacy Questionnaire (TALQ), it reveals that the average level of teachers' assessment literacy is moderate. The data show that teachers have adequate knowledge of selecting the assessment objectives that fit learning goals and construct a valid test. It is slightly more significant than the findings from Alkharusi et al. (2012), Muhammad and Bardakçi (2019), and Yamtim and Wongwanich (2014). However, participants still need more exposure to assessment knowledge through some professional development activities.

In the Indonesia context, Puspawati (2019) reports on her study that the language assessment literacy of teachers in higher education in Indonesia is at a reasonable level. It means that teachers in the tertiary education level have moderate knowledge, skills, and language assessment principles. However, the interview data highlight that they have more knowledge and skills in teaching than in language assessment because they have limited professional training, which focuses on assessment. An empirical study from Marhaeni et al. (2018) indicates that Bali's authentic assessment practice was failed because the teachers have limited assessment knowledge and skills designing authentic tasks and reporting assessment results. It is strongly suggested that the assessment training helps the teachers support their assessment practice (Babaii \& Asadnia, 2019). Although teachers' assessment literacy level is moderate, they still need to develop and update their assessment literacy and skill, which meet the standard of learning goals.

Journal on English as a Foreign Language, 10(2), 421

p-ISSN 2088-1657; e-ISSN 2502-6615 
To obtain a more in-depth understanding of EFL secondary teachers' assessment literacy, this study invited three participants-teachers from a different level of assessment literacy to seek teachers' assessment conceptions, the procedure of designing assessment tasks, and the challenges in assessment practice. All teachers agree that assessment is crucial in the teaching and learning process. A teacher who has high assessment literacy admits her conceptions that assessment aims to improve learning and measure the students' achievement in learning. On the contrary, low and moderate-level teachers tend to have more conceptions on assessment OF learning purposes than assessment FOR learning purposes. The resembling views are commonly found in some studies conducted in some countries with high-stake educational assessment systems, such as Hong Kong, China, Indonesia, and other countries in Asia (Azis, 2015; Koh et al., 2018; Lam, 2015).

When discussing the designing assessment procedure, all the participants spontaneously referred assessment to "testing" or "examination." This situation is similar to Berry et al. (2019) finding when they interviewed three teachers working at UK University. It seems that teachers are more familiar with testing than assessment activities. Furthermore, in the interview, participants used a blueprint from the school or regional community of professional development as the guideline to design a test. Although they were not aware of assessment principles, such as validity, reliability, practicality, authenticity, and other principles, they unconsciously did a construct validity test in designing test items. The result is in line with a study done by Lam (2019). He concludes that Hong Kong secondary teachers have a better knowledge of assessment than the use of reliability and validity.

Interestingly, participants reveal that senior teacher or mentor teacher has a crucial role in assisting teacher, especially for a novice teacher, in implementing their assessment knowledge into practice. Correspondingly, $\mathrm{Xu}$ and Brown (2016) assert that the teachers' assessment practice is not merely developed from the influence of knowledge and skill. However, it entangles some complex factors, including teachers' conception, policy, and socio-culture. In this case, colleagues can collaborate by sharing knowledge and experience, discussing the task construction, observing each other in their classroom assessment practice, and asking one another (Babaii \& Asadnia, 2019).

Regarding some constrains in assessment practice, participants face some challenges. Due to the institutional policy of using online test applications, the teacher cannot provide a subjective test or essay test to the students because the

Journal on English as a Foreign Language, 10(2), 421

p-ISSN 2088-1657; e-ISSN 2502-6615 
tool only facilitates the objective test. Lam (2019) suggests that principals should provide teachers with an opportunity to practice some alternative assessments (e.g., providing feedback, doing self-reflection in a portfolio, conducting peer evaluation) to develop their assessment practice.

Furthermore, teachers admit that they are lack confidence in doing assessments due to their limited knowledge and skill in doing assessments. They wish that they can attend some training which specifically discusses assessment. Saputra et al. (2020) conducted a professional learning community project focusing on language assessment literacy in six months. The result shows that PLC projects can surge teachers' understanding of assessment literacy, particularly in authentic assessment practices. Besides, Livingston and Hutchinson (2017) convince that implementing an ongoing career-long professional learning (CLPL) can effectively improve teachers' assessment effectiveness. In short, various professional assessments training conducting in sufficient time results in teachers' knowledge and assessment skills.

On the other hand, the participants also confess that the national curriculum changing significantly impacts assessment policy. That situation happened many times in the educational system in Indonesia. It may cause teachers' burnout to update their assessment knowledge and day-to-day classroom assessment practice. Zulaiha et al. (2020) conducted a semistructured interview with several EFL teachers in Indonesia to investigate their assessment literacy training needs. The findings reveal that teachers need some practical assessment training with specific content, such as constructing Higher Order Thinking Skills (HOTS) Questions and deploying technology in assisting classroom assessment.

All in all, EFL secondary teachers generally have a reasonable level of assessment literacy. However, some of them still view assessment merely as a tool for scoring or measuring students' achievement toward the learning output. They need to have more literacy and skills exposures to develop their conceptions, literacy, and classroom assessment skills. Moreover, the curriculum shift in a short period might hinder teachers' understanding of daily assessment implementation. Following that, they need to have professional training that focuses on specific assessment content regularly. Additionally, the levels of assessment literacy reflect the teachers' assessment practice. 


\section{CONCLUSION}

There are some highlighted points from this study that can contribute to the body of assessment knowledge. First, EFL secondary in Indonesia has a moderate level of assessment literacy. Second, teachers' day-to-day classroom assessment practices are affected by individual assessment literacy, institutional and national policies, and socio-culture elements. Finally, there is an urgency to provide some exposure to the EFL secondary teachers on utilizing assessment to improve students' learning and assist the teacher in enhancing their learning instructions through some regular professional training, which focuses on classroom assessment practice. The training can be initiated by the school principal, MGMP, or other learning communities. On the other hand, the present study has a limitation on the number of participants and the setting of study; it involved only EFL secondary teachers in one city. Future research might consider involving a higher number of participants and broader settings. It is appealing to scrutinize the effect of assessment training that attempts to enhance teachers' knowledge and conceptions on assessment FOR learning or alternative assessment to students' learning improvement. Besides, the impact of a mentor teacher is also an enticing issue to be explored.

\section{ACKNOWLEDGEMENTS}

This work is supported and funded by Lembaga Penelitian Universitas Swadaya Gunung Jati Cirebon, West Java-Indonesia. The greatest appreciation also goes to all respondents, English secondary teachers, who have voluntarily been involved in this research.

\section{REFERENCES}

Alkharusi, H., Aldhafri, S., Alnabhani, H., \& Alkalbani, M. (2012). Educational assessment attitudes, competence, knowledge, and practices: An exploratory study of Muscat teachers in the Sultanate of Oman. Journal of Education and Learning, 1(2), 217-232. https://doi.org/10.5539/jel.v1n2p217

Azis, A. (2015). Conceptions and practices of assessment: A case of teachers representing improvement conception. TEFLIN Journal, 26(2), 129-154. https://doi.org/10.15639/teflinjournal.v26i2/129-154

Babaii, E., \& Asadnia, F. (2019). A long walk to language assessment literacy: EFL teachers' reflection on language assessment research and practice. Reflective Practice, 20(6), 745-760. https://doi.org/10.1080/14623943.2019.1688779 
Barnes, N., Fives, H., \& Dacey, C. M. (2017). U.S. teachers' conceptions of the purposes of assessment. Teaching and Teacher Education, 65, 107-116. https://doi.org/10.1016/.tate.2017.02.017

Berry, V., Sheehan, S., \& Munro, S. (2019). What does language assessment literacy mean to teachers? ELT Journal, 73(2), 113-123. https://doi.org/10.1093/elt/ccy055

Bijsterbosch, E., Béneker, T., Kuiper, W., \& van der Schee, J. (2019). Teacher Professional growth on assessment literacy: A case study of prevocational geography education in the Netherlands. The Teacher Educator, 54(4), 420-445. https: //doi.org/10.1080/08878730.2019.1606373

Braun, V., \& Clarke, V. (2006). Using thematic analysis in psychology. Qualitative Research in Psychology, 3(2), 77-101. https://doi.org/10.1191/1478088706qp063oa

Cheng. (2017). Assessment in the language classroom. Palgrave. Retrieved from https://ink.springer.com/book/10.1057 978-1-137-46484-2

Cohen, L., Manion, L., \& Morrison, K. (2007). Research methods in education (6th ed.). Routledge.

DeLuca, C., \& Klinger, D. A. (2010). Assessment literacy development: Identifying gaps in teacher candidates' learning. Assessment in Education: Principles, Policy $\mathcal{E} \quad$ Practice, 17(4), 419-438. https://doi.org/10.1080/0969594X.2010.516643

Deneen, C. C., \& Brown, G. T. L. (2016). The impact of conceptions of assessment on assessment literacy in a teacher education program. Cogent Education, 3(1). 1-14. https://doi.org/10.1080/2331186X.2016.1225380

Duckor, B., \& Perlstein, D. (2014). Assessing habits of mind: Teaching to the test at central park east secondary school. Teachers College Record, 116(2), 1-33. Retrieved from https://www.tcrecord.org/

Fan, Y.-C., Wang, T.-H., \& Wang, K.-H. (2011). A web-based model for developing assessment literacy of secondary in-service teachers. $\begin{array}{llll}\text { Computers } & \mathcal{E} & \text { Education, } & \text { 57(2), }\end{array}$ https://doi.org/10.1016/.compedu.2011.03.006

Fulcher, G. (2012). Assessment literacy for the language classroom. Language Assessment Quarterly, 9(2), 113-132. https://doi.org/10.1080/15434303.2011.642041

Koh, K., Burke, L. E. C.-A., Luke, A., Gong, W., \& Tan, C. (2017). Developing the assessment literacy of teachers in Chinese language classrooms: A focus on assessment task design. Language Teaching Research, 22(3), 264-288. https://doi.org/10.1177/1362168816684366 
Koh, K. H. (2011). Improving teachers' assessment literacy through professional development. Teaching Education, 22(3), 255-276. https://doi.org/10.1080/10476210.2011.593164

Lam, R. (2015). Language assessment training in Hong Kong: Implications for language assessment literacy. Language Testing, 32(2), 169-197. https://doi.org/10.1177/0265532214554321

Lam, R. (2019). Teacher assessment literacy: Surveying knowledge, conceptions and practices of classroom-based writing assessment in Hong Kong. System, 81, 78-89. https://doi.org/10.1016/1.system.2019.01.006

Lee, I. (2013). Becoming a writing teacher: Using "identity" as an analytic lens to understand EFL writing teachers' development. Journal of Second Language Writing, 22(3), 330-345. https://doi.org/10.1016/j.jslw.2012.07.001

Lee, I., \& Coniam, D. (2013). Introducing assessment for learning for EFL writing in an assessment of learning examination-driven system in Hong Kong. Journal of Second Language Writing, 22(1), 34-50. https://doi.org/10.1016/j.jslw.2012.11.003

Levi, T., \& Inbar-Lourie, O. (2020). Assessment literacy or language assessment literacy: Learning from the teachers. Language Assessment Quarterly, 17(2), 168-182. https://doi.org/10.1080/15434303.2019.1692347

Levy-Vered, A., \& Alhija, F. N.-A. (2018). The power of a basic assessment course in changing pre-service teachers' conceptions of assessment. Studies in Educational Evaluation, 59, 84-93. https://doi.org/10.1016 h.stueduc.2018.04.003

Livingston, K., \& Hutchinson, C. (2017). Developing teachers' capacities in assessment through career-long professional learning. Assessment in Education: Principles, Policy E Practice, 24(2), 290-307. https://doi.org/10.1080/0969594X.2016.1223016

Looney, A., Cumming, J., van Der Kleij, F., \& Harris, K. (2018). Reconceptualising the role of teachers as assessors: Teacher assessment identity. Assessment in Education: Principles, Policy E Practice, 25(5), 442467. https://doi.org/10.1080/0969594X.2016.1268090

Muhammad, F. H. N., \& Bardakçi, M. (2019). Iraqi EFL teachers' assessment literacy: Perceptions and practices. Arab World English Journal, 10(2), 431442. https://doi.org/10.24093/awej/Nol10no2.33

Pastore, S., \& Andrade, H. L. (2019). Teacher assessment literacy: A threedimensional model. Teaching and Teacher Education, 84, 128-138. https://doi.org/10.1016/.tate.2019.05.003 
Plake, B. S., Impara, J. C., \& Fager, J. J. (1993). Assessment competencies of teachers: A national survey. Educational Measurement: Issues and Practice, 12(4), 10-12. https://doi.org/10.1111/1.1745-3992.1993.tb00548.x

Prasetyo, A. H. (2018). Language assessment literacy development: A studentteacher's experiences in teaching practice program. LLT Journal: A Journal on Language and Language Teaching, 21, 199-206. https:// doi.org/10.24071/1lt.2018.210209

Puspawati, I. (2019). Understanding teachers' knowledge, skills, and principles on language assessment: A survey on teachers' language assessment literacy. In Proceedings of the Third International Conference on Sustainable Innovation 2019 - Humanity, Education and Social Sciences (IcoSIHESS 2019). Atlantis Press. https://doi.org/10.2991/icosihess-19.2019.11

Saputra, E., R., Hamied, F. A., \& Suherdi, D. (2020). The development of beliefs and practices of language assessment literacy: Does a professional learning community help? Journal of Education for Teaching, 46(3), 414416. https://doi.org/10.1080/02607476.2020.1761250

Scarino, A. (2013). Language assessment literacy as self-awareness: Understanding the role of interpretation in assessment and in teacher learning. Language Testing, 30(3), 309-327. https://doi.org $/ 10.1177 / 0265532213480128$

Stiggins, R. J. (1991). Assessment literacy. Phi Delta Kappan, 72(7), 534-539. Retrieved from https://ournals.sagepub.com home/pdk

Vogt, K., \& Tsagari, D. (2014). Assessment literacy of foreign language teachers: Findings of a European study. Language Assessment Quarterly, 11(4), 374402. https://doi.org/10.1080/15434303.2014.960046

Xu, Y., \& Brown, G. T. L. (2016). Teacher assessment literacy in practice: A reconceptualization. Teaching and Teacher Education, 58, 149-162. https://doi.org/10.1016/.tate.2016.05.010

Yamtim, V., \& Wongwanich, S. (2014). A study of classroom assessment literacy of primary school teachers. Procedia - Social and Behavioral Sciences, 116, 2998-3004. https://doi.org/10.1016/.sbspro.2014.01.696

Zulaiha, S. (2020). Exploring junior high school EFL teachers' training needs of assessment literacy. Cogent Education, 7(1), 1-13. https://doi.org/10.1080/2331186X.2020.1772943 


\section{Authors' Brief CV}

Roghibatul Luthfiyyah is a faculty member of Universitas Swadaya Gunung Jati Cirebon, West Java, Indonesia. She is currently pursuing her doctorate degree at Universitas Negeri Malang. Her research interests are in the area of assessment in language teaching, technology-enhanced language learning, and teachers' professional development.

Iin Wariin Basyari is a faculty member of Universitas Swadaya Gunung Jati Cirebon, West Java, Indonesia. He earned his master's and a doctoral degree from UPI Bandung. His research interests are social science, local wisdom, and character-building.

Dwiniasih currently teaches the undergraduate student in Universitas Swadaya Gunung Jati Cirebon, West Java, Indonesia. She graduated from UNNES. Her research interest is in prospective teacher management in teaching. 